\title{
Situating the East Indonesia's EFL learners' attitudes toward the extensive listening practices
}

\author{
Yosefina Rosdiana Su, Fatmawati, Stanislaus Guna, Fransiskus Jemadi, \\ Yovita Narsi Mat, Ronaldus De'e \\ English Language Education Department, Universitas Katolik Indonesia Santu Paulus \\ Ruteng, Flores, Nusa Tenggara Timur, Indonesia
}

\author{
*Corresponding Author \\ Email: josephinesu517@gmail.com
}

Received:

31 January 2021
Revised:

25 February 2021
Accepted:

20 August 2021
Published:

31 August 2021

\begin{abstract}
Learning English as a foreign language is very challenging for both teachers and students in Flores, East Nusa Tenggara of Indonesia. The challenges are primarily caused by their lack of exposure to the authentic environment of English. In dealing with this phenomenon, the appropriate listening practices expect to help the learners to obtain and construct their knowledge of English as well as to acquire more comprehensible input. This article reports an investigation on the EFL learners' attitudes toward the extensive listening practices. It applied mixed-method research procedures involving 55 students of the English language and education program of Universitas Katolik Indonesia Santu Paulus Ruteng. The data were collected through a survey coupled with Focus Group Discussions with 15 participants. This research revealed that the learners' attitudes are identified into two main categories called positive and negative attitudes. In this case, $38 \%$ of the participants have positive attitudes toward extensive listening practices and $62 \%$ of the participant reflected the negative attitude toward the extensive listening practices. Learners with a positive attitude had a very strong awareness of the significance of listening skills in L2 learning. To improve their listening skills, they develop their listening practices outside the classroom consistently. Meanwhile, learners with negative attitudes were categorized as dependent learners who practiced their listening skills during the listening course only. This group of learners was less aware of the significance of listening skills in L2 learning and their listening practices were highly dependent on the teachers' instruction. It showcased that both of the learners' internal and external factors were strongly contributed to this poor extensive listening practices. The EFL teachers are then strongly suggested to strengthen the learners' awareness on the significance of Listening Skills in L2 learning as well as design more instructed extensive listening practices outside the classroom.
\end{abstract}

Keywords: learners' attitudes; extensive listening; EFL

\section{INTRODUCTION}

In learning English as a Foreign Language (EFL), learners must be exposed to the four basic language learning skills called Reading, Speaking, Writing, and 
Listening. Although the skills considered as stand-alone courses, these four skills principally work together as a system to support the process of EFL learning (Vandergrift \& Goh, 2012). However, among the other skills, listening skills are considered as the basic foundation for the establishment of other literacy skills, especially oral skills (Field, 2009; Vandergrift \& Goh, 2012). In this case, as speaking does, listening is also crucial for everyone in maintaining effective communication in both daily and academic contexts.

Recent studies in English language teaching showcased that listening skills' appropriate practices will effectively increase the learners' exposures to the diversity of English and acquire the necessary input for their L2 acquisition (Hamouda, 2013; Renandya, 2011; Rost, 2011). Besides, learning to listen to the target language does improve the language comprehension, in which, learners accustomed to the speech rate, pronunciation, rhythm, intonation, stress, or the variety of spoken and colloquial expressions used in the target language (Chang \& Millet, 2013). It also enables the learners to expose to the variety of spoken discourse that can support their foreign language proficiency (Gilliland, 2015). Not surprisingly, listening skills improved the development of other skills (Krashen \& Terrell, 1983; Rost, 2011). Thus, the EFL teachers are expected to initially highlight the students' awareness of the primacy of listening skills and its core function for EFL learning.

However, there is a significant distinction between listening skills development in both L1 and L2 contexts. In L2 learning, it engages the learners in a complex comprehension process of understanding, integrating and responding the verbal utterances being said. On the other hand, this process requires the learner to activate their various types of knowledge in order to construct an appropriate interpretation of what has been said. In the L1 acquisition, listening skills are considered to be naturally developed even without specific effort or attention (Rost, 2011). On the other side, in the EFL context, listening activity is seemingly done as learning to listen rather than to listen to itself. Interestingly, learners could even get difficulties recognizing the words, phrases, or sentences they might have familiar in print (Setyowati \& Kuwahono, 2018) a result, they fail to convey the spoken message and view listening as the most complicated skill to master (Renandya, 2016).

For EFL learners, specific strategies are usually needed to cope with the complication of listening skills. Meanwhile, the appropriate learning instruction, including the curriculum, is also acknowledged as the vital instrument that contributes to the learners' listening improvement. It will be harder for the learners to improve their listening skills when the curriculum designed relied more on the improvement of written and other literacy skills, which predominantly highlight the writing practices and ignore the necessary communicative skills such as speaking and listening (Renandya \& Hu, 2018). Furthermore, the listening practice is more disregard and learners squander the crucial resources to acquire the understandable input of the foreign language being learned.

In East Nusa Tenggara of Indonesia, especially in the English Language and Education Program of Universitas Katolik Indonesia Santu Paulus Ruteng, listening skill is taught as a stand-alone course programmed once a week with 90 minutes time allocation. Moreover, the listening comprehension 
instructions are designed as the intensive that basically focus on grammar and vocabulary acquisition. In its practice, the listening course tends to be set up as passive skills, in which the learners are merely responding to the prerecording audios/videos through some comprehension tasks. It then eventually puts it as the most tedious course for both learners and teachers.

As it is taught as a foreign language subject, the target language learning's authentic resources are extremely restricted. It is to say that, most comprehensible inputs are obtained only from the classroom interaction, especially from the listening courses. It can be strongly assumed that the learners have very limited opportunities to cope with listening practices. The weekly class's 100 minutes must not be enough for learners to improve their skills to listen to the target language. Thus, it is a must for teachers to drive their learners to have more listening practices outside the classroom to improve their competence in comprehending the spoken language. Based on the significant contribution of listening skills for the students' foreign language improvement, this research was aimed at investigating the practices of Extensive Listening among the students of English and Education Program in Universitas Katolik Indonesia Santu Paulus Ruteng, East Nusa Tenggara. The researchers have a firm intention to identify how extensive listening works among the EFL learners in this context and their impacts on their English proficiency.

\section{Extensive listening in EFL classroom}

Learning to listen in the L2 context takes a lot of time and more thoughtful efforts, in which learners need to practice to listen anytime and anywhere more than what they acquire in the class. Thus, learners are expected to manage more outclass listening practices to think about how they listen and what they could do to improve their listening skills (Gillian, 2015). EFL teachers can expose the learners to the target language through comprehensive listening practices (Renandya, 2011; Renandya \& $\mathrm{Hu}, 2018$ ).

Besides, many researchers have also viewed that extensive exposure to the target language is exceedingly worthwhile for L2 learning (Krashen \& Terrel, 1983). More listening practices are assumed will enable the learners to comprehend their listening difficulties in understanding, receiving, making meaning from, and responding to verbal and non-verbal messages (Abbas \& Narjes, 2016). Thus, the EFL teachers need to expose the learners to a variety of listening strategies, such as through Extensive Listening.

Extensive listening is primarily defined as "all types of listening activities that allow learners to receive a lot of comprehensions and enjoyable listening input (Renandya \& Farrell, 2011; Widodo \& Rozak, 2016). Contrasting to the rigid concept of intensive listening, which emphasizes teaching grammar and vocabulary, extensive listening helps the learners obtain the language benefits in a more enjoyable and pleasurable way. Furthermore, extensive listening is also defined as a listening strategy that encourages the students to listen to the self-selected and the variety of listening materials appropriate with the level of their comprehension (Widodo \& Rozak, 2016).

This definition highlights three main points. The first point is the selfselection of listening materials. Having the students selecting the materials based on their interests will reinforce their motivation to practice and continue 
practicing in their own time. Secondly, listening to a variety of materials. Apart from spending long periods listening, assigned the students to listen to the wide numbers of materials will help them to expose to different types of discourse (e.g., dialogic speech, accents, cultures). Thirdly, the materials' level is supposed to be appropriate with their needs and level of comprehension, whether it is at or below (Vandergrith \& Goh, 2012).

Moreover, the current L2 listening pedagogy encourages teachers to pay attention not only to the product but also the process of listening (Renandya $\&$ $\mathrm{Hu}, 2018$ ). In this case, extensive listening can effectively help both teachers and learners to focus on the process. It takes teachers in a better position to support learners who might experience processing problems at listening in the target language. Adequate exposure to abundant input and sustained practice can lead to listening fluency (Chang \& Millet, 2014). Researches in listening have also revealed that setting up the extensive listening strategy in learning to listen to the L2 is beneficial for the learners. It helps learners establish their cognitive map to obtain the fundamental knowledge related to the use of the target language (Nation \& Newton, 2009, as cited in Renandya, 2011). For the lower proficiency learners, repeated listening and extensive listening practices will also help them control the speech rate in learning to interpret the diversity of spoken language.

\section{METHOD}

This research was designed as the mixed methods research, in which the qualitative and quantitative research procedures were applied in collecting and analyzing the data. This design enables the researchers to integrate the findings and the inference following the qualitative and quantitative approaches. It also enables the researcher to combine the elements of qualitative and quantitative research approaches for the broad purposes of breadth and depth of understanding and corroboration (Johnson et al., 2007; Tashakkori \& Creswell, 2007). In this research, the researchers conducted a survey and some focus group discussions to obtain the data, which indicates the combination of qualitative and quantitative research procedures.

\section{The respondents}

This study involved 55 third grade students of the Language and Education Program of Universitas Katolik Indonesia Santu Paulus Ruteng, East Nusa Tenggara, Indonesia. They were involved since they have passed six credits of listening courses, namely and considered to have prior knowledge of the issue being discussed.

Table 1. Research respondents

\begin{tabular}{ccc}
\hline No & Gender & Total \\
\hline $\mathbf{1}$ & Female & 31 \\
$\mathbf{2 .}$ & Male & 24 \\
\hline & Total Respondents & 55 \\
\hline
\end{tabular}




\section{Instruments}

The data were obtained through a survey using a questionnaire consisted of 15 close-ended questions using a Likert scale $(1=$ strongly disagree, 2 =disagree, 3=agree, 4=strongly agree) approach and two open-ended questions. The questionnaire was developed through a comprehensive review toward some fundamental theories about extensive listening (Renandya \& Farrell, 2011; Renandya \& Jacobs, 2016; Waring, 2008) as well as some result of the previous studies about extensive listening (Chang $\&$ Millet, 2012; Chang $\&$ Millett, 2014; Lee \& Cha, 2017; Takaesu, 2013).

Besides, three sessions of the focus group discussions (FGD) were also conducted as the follow-up data collection technique. This FGD involved only 15 students as the sample of the research. Each discussion was administered in about 60 minutes and focusing on elaborating on the learners' experiences in practicing the extensive learners. This FGD facilitated the researchers to view more information on the variety of extensive learners used to do and how its impact on their English improvement.

\section{RESULT AND DISCUSSION \\ Facts on the extensive listening practices}

This study was primarily aimed at investigating the facts related to the practices of extensive listening among the EFL learners of the English Language and Education Program at Universitas Katolik Santu Paulus Ruteng. Through this study, the researchers tried to situate how the learners manage their out classroom listening activities and identify its impacts on their individuals' language improvement. Through a survey and sessions of FGDs, it was found that some critical facts related to the extensive listening practices might be unrecognized even by the lecturers who taught the subject as presented in figure 1 :

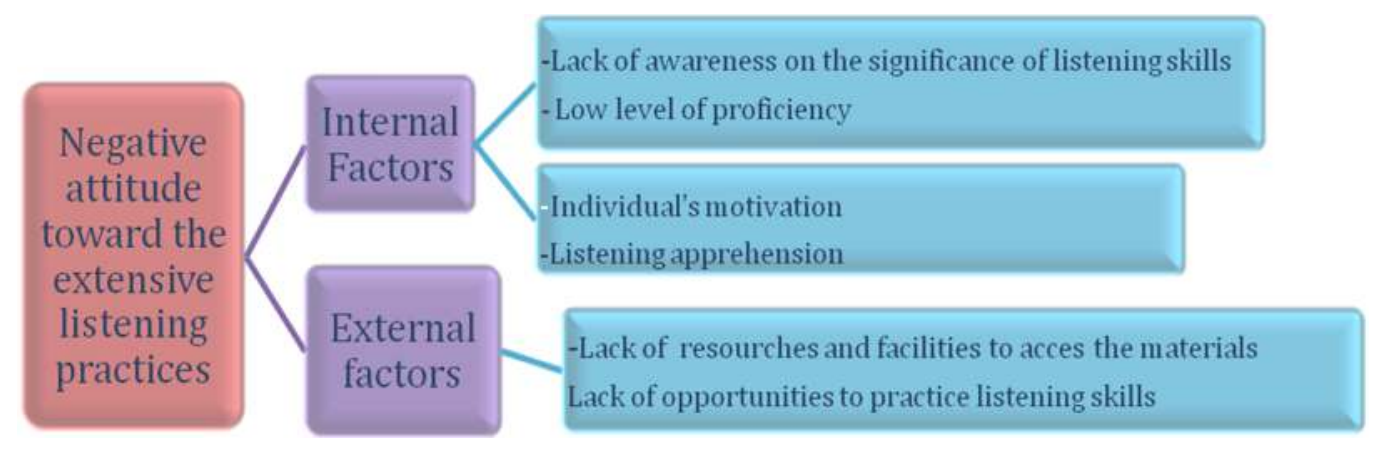

Figure 1. Facts on the practices of extensive listening

This investigation showcased that the majority of participants reflected the negative responses toward the practices of extensive listening. It is to say that most of the learners involving in this study were simply neglecting the extensive listening practices because of two significant reasons comprising the learners' internal and external factors.

This study found that most of the respondents were not aware of the importance of extensive listening as an effective strategy in improving their listening competence. Only few students realized its significance and 
consistently did the extensive listening practices outside the classroom. Furthermore, listening was still labeled as the passive skill in which, superficially, the learners seem to only sit in a language laboratory quietly, listened to pre-recorded dialogues, and wrote the answers to some questions related to the oral stimulus without any interactive activities. As a result, extensive listening practices were not passionately and systematically managed.

\section{Lack of awareness on the importance of listening skills in L2 learning}

The Internal factors were mostly related to the learners' lack of awareness on the significance of listening skills and how it works in individuals' process of L2 acquisition. In the EFL context, learners must initially understand that conveying the message in a real communication happens through listening; thus, learners must also be fluent in listening. Many studies in L2 acquisition argue that listening is the foundation of speaking because the learners' fluency in listening will potentially contribute to their speaking fluency (Rost, 2011; Spear \& Swerling, 2016;). Furthermore, promoting the learners' awareness of the function of listening skills in L2 learning is supposed to be the responsibility of each EFL teachers. Learners need to be initially exposed to listening skills' role beyond the teaching of listening strategies. It is to say that teachers are expected to be the scaffolders who can facilitate the learners to listen as well as listening to learn.

Besides, this group of learners viewed listening as less important than speaking, reading, writing, and other literacy skills. In their mindset, their language proficiency is best performed through their speaking ability. Surprisingly, the learners were less aware that speaking competence required both receptive and productive skills to send and understand the verbal messages. Moreover, to be able to speak in a foreign language, learners needed to be well accustomed to the sound system of the target language, which can only be acquired through listening.

\section{Learners' low level of English proficiency}

As presented in figure 1, the low level of English proficiency was also indicated as a factor contributing to the poor extensive listening practices among the participants. It showcased that the majority of the participants belong to a low level of proficiency. This fact indicated that the learners' cognitive aspects of listening are encountered as the most challenging subjects to deal with. The significant aspects of difficulties were their inability to recognize the phonetic variations, control the speech rate, and identify the spoken expressions. Besides, they also found difficulties recognizing the words, sentences, or phrases being heard and identifying the speakers' accents, limited vocabulary mastery, and the lack of contextual knowledge. The following are the sample information reported by the participants related to their difficulties in listening:

'Its' very hard for me to control how quickly the speakers talked.

Moreover, I could not have words repeated." (MTF)

"I often fail in recognizing the phonetic variations and categorize the words listened into a meaningful unit" (DN) 
As reported by the participants, many researchers in listening have also assumed that the general factors identified as the common difficulties encountered by the low proficiency EFL learners are related to speech speed, speech variety, and the blurriness of word boundaries (Renandya \& Farrell, 2011). The earlier studies have also revealed that the difficulties of L2 listening are mostly related to the inability to control speech rate, phonological features, syntactic complexity, and prior knowledge. it also associated with the lack of vocabulary mastery, the unfamiliar accents, and the verbal language's structure and syntax (Chang, 2012; Takaesu, 2013; Su et. al., 2019). Furthermore, another critical thing to highlight is the low proficiency students' problem with unknown words was driven not only by their lack of vocabulary mastery but also their inability to correctly infer the meaning of unfamiliar words from the contexts.

\section{Listening apprehension}

Surprisingly, this low level of English proficiency was also impacted to the learners' psychological and inner motivation in learning to listen in L2. Their low cognitive complexity of listening skills had put much stress and other psychological problems that successfully killed the learners' motivation to learn to listen in the target language. This substantial problem has made the learners lose their hearts in listening, as stated below:

\footnotetext{
"If the speed is too fast, I tend to feel nervous, and I'm likely to give up listening" (MJ)

"I often find my self-confidence ruined when I fail to identify the unfamiliar words or accent of the speaker" (LMD)

"I used to feel depressed when I cannot construct the oral messages of the delivery speech, and eventually I lose their words to give the appropriate response" (AGT)

"I always get nervous when I join the listening course. My feeling of afraid breaks my focus so that I cannot follow the lesson conveniently" (YNR)
}

In this study, most of the participants admitted that listening skills are much stressful and very hard to master. As a result, they get less motivated and continue neglecting it. In this context, listening apprehension is assumed to be the result of listeners' inability to comprehend the verbal messages. A study on language apprehension described that many L2 learners get high anxiety of listening due to some reasons such as fail to comprehend the message or unfamiliar vocabulary used in the materials being heard ( $\mathrm{Su}$, et. al. 2019). These aspects of difficulties had contributed to their lack of motivation and self-confidence in learning to listen in L2.

\section{Lack of access to extensive listening materials}

The extensive listening practice can actually help the L2 learners to handle their listening difficulties as well as establish their self-confidence and learning motivation. Regular extensive listening practices will enable the L2 learners to develop their word recognition skills, enabling them to move over 
words in meaningful chunks with sufficient speed, with ease and with greater comprehension (Chang \& Renandya, 2018). When learners were accustomed to the speed rate of various contexts of the verbal message, their comprehension in constructing the meaning of the verbal messages will be well developed.

Interestingly, although this skill is tough to master, most of the participants admitted that they had very limited time to practice listening. Most of them dealt with listening practices only in the classroom, which is programmed once a week. The extensive listening practices outside the classroom were developed solely for the official listening tasks assigned by the lecturer seen in figure 2.

A significant reason for this lack of practice was due to the lack of facilities to access the materials from the internet. In this case, $18 \%$ of learners did not utilize the android version of the mobile phone. This condition was due to their financial condition, and it was often out of their control. As a result, the learners got a minimal opportunity to listen and absolutely impact their English proficiency. However, $82 \%$ of the respondents used their mobile phones to access the listening materials and utilized them as their primary tools to improve their listening skills-the used variety of applications to learn to listen in English.

This research also investigated the listening materials used in their extensive listening practices. It was reported that the majority of the participants had been accustomed to some internet-based materials, which proved that the learners had learned to put technology in their learning process. The platforms such as YouTube, Podcast, BBC, VOA, or CNN had utilized by the participants to support their listening practices. It was easy for them to get the material from the internet; moreover, they could freely select the contents based on their areas of interest. The figure 2 presents the types of learning material utilized by the participants:

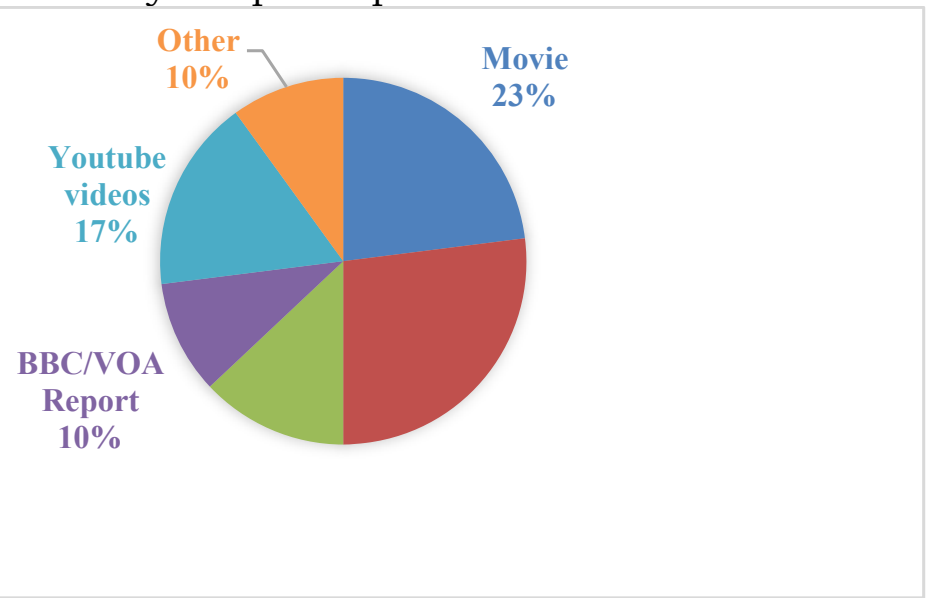

Figure 2. Types of extensive listening materials

The majority of students did the kinds of easy listening practices outside the classroom. They set the materials based on their interest, which were also met their level. It helped them to enjoy listening and did not take it as a burden. It was revealed that there are $27 \%$ of the participants who were easily practicing listening by enjoying their favorite songs available on their phones. 
It helped them improve their comprehension of the gist and the detailed meaning of the song, more vocabulary mastery, and at the same time, more motivated in listening.

It was also found that $23 \%$ of the respondents enjoyed the movies as part of their extensive listening practice. They revealed that watching the movies helped them to rehearse their listening comprehension in such an authentic situation. Besides, the movie helped them improve their knowledge of colloquial expressions and other spoken expressions such as slang words and idioms.

There were also $17 \%$ of the participants had utilized YouTube videos as extensive listening tools. They admitted that different movies, YouTube videos were easier to access, in which, they just needed an android and internet connection. It was also more portable for the learners since they can do it everywhere and any time they need.

\section{Lack of listening practices}

This research revealed that the participants reported different responses to the frequency of their out classroom listening habits. It was reported that there were $46 \%$ of the participants extending their listening practices outside the classroom sometimes. They admitted that they did not do extensive listening unless assigned to manage an extensive listening project during the semester (4-5 times in a semester). It means that this group of students was not independently and consciously practicing extensive listening. Thus, it can be indicated that $46 \%$ of the participants did not extend their listening practices regularly.

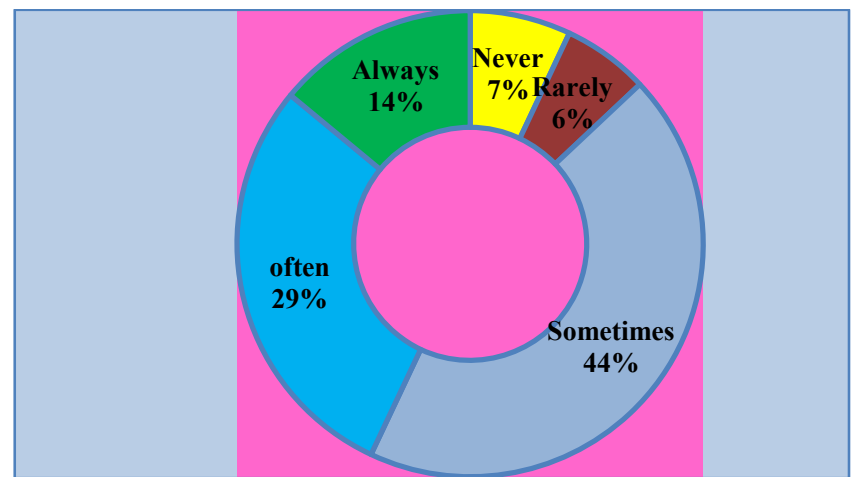

Figure 3. The frequency of the extensive listening practices

Interestingly, there are still $6 \%$ of the participants who rarely did extensive listening activities. Meanwhile, there were $7 \%$ of them who never did extensive listening practices. This indicated that $59 \%$ of the participants ignored the extensive listening practices for some critical reasons that have been elaborated.

$30 \%$ of students indicated in the blue area of the figure were considered often do extensive listening practices, which means that the extensive listening activities took 3-4 times a month. This group of students does extensive listening in their spare time by watching movies, listening to English songs, or 
news. Interestingly, there were only $11 \%$ of the participants always do extensive listening practice. They did it by listening to accessible listening materials, such as songs, movies, or YouTube videos. They almost did it every day as part of their hobbies. They learned how to take advantage of the things they love to do, especially in improving their English. Some of them were even subscribing to some online listening channels to get more internet-based listening material.

\section{CONCLUSION}

Due to the L2 learners' lack of awareness of the critical Listening comprehension skills teachers must strengthen the students' basic understanding of the nature of listening skills and its function in language learning. In this case, the teachers' role is crucial. Teachers need to push the learners to do more listening practices outside the classroom and engage their learners to be accustomed to the digital features they can access to improve their listening proficiency. Furthermore, teachers' consistency in pushing the students to practice extensive listening is a must, indeed.

Many listening instructors paid more attention to give too many listening tasks to their students. They ignored their role in reminding the learners of the essential aspects of listening skills in a foreign language process. The problems found in listening should not be considered as the reasons for being less motivated to master this skill but needed to be taken as a motivation to keep learning. They had to realize that, whether they like it or not, listening skill will influence their communicative competence in using the target language. Teachers need to support and push the learners to have more listening practices outside the classroom by utilizing the easiness offered by this digital era.

\section{ACKNOWLEDGEMENTS}

We would like to express our sincere gratitude to Edulite: Journal of English Education, Literature, and Culture for publishing this article. The same gratitude goes to the third grade students of English Language and Education program of Universitas Katolik Santu Paulus Ruteng and everyone who have helped this research.

\section{REFERENCES}

Gilakjani, A. P., \& Sabouri, N. B. (2016). Learners' listening comprehension difficulties in English language learning: A literature review. English language teaching, 9(6), 123-133. http://dx.doi.org/10.5539/elt.v9n6p123

Chang, C. S. A. (2012). Gains to L2 learners from extensive listening: listening development, vocabulary acquisition and perceptions of the intervention. Hong Kong Journal of Applied Linguistics, 14(1), 25-47.

Chang, C. S. A., \& Millett, S. (2013). The effect of extensive listening on developing L2 listening hard evidence. ELT Journal, 68(1), 31-40, http://dx.doi.org/10.1093/elt/cct052 
Chang, A. C., \& Millett, S. (2014). The effect of extensive listening on developing L2 listening fluency: Some hard evidence. ELT journal, 68(1), 31-40. http://dx.doi.org/10.1093/elt/cct052

Chang, A., Millett, S., \& Renandya, W. A. (2019). Developing listening fluency through supported extensive listening practice. RELC Journal, 50(3), 422-438. https://doi.org/10.1177/0033688217751468

Field, J. (2009) More listening or better listeners? ENGLISH Teaching Professionals, 61,12-14.

Gilliland, B. (2015). Listening logs for extensive listening practice. In D. Nunan \& J. C. Richards (Eds.), Language learning beyond the classroom (pp. 13-22). Routledge.

Hamouda. A. (2013). An investigation of listening comprehension problems encountered by saudi students in the el listening classroom. International Journal of Academic Research in Progressive Education and Development, 2(2), 113-155.

Johnson, R. B., Onwuegbuzie, A. J., \& Turner, L. A. (2007). Toward a definition of mixed methods research. $J$ Mixed Methods Res 1, 112-133. https://doi.org/10.1177\%2F1558689806298224

Krashen, S., Terrell, T. (1983). The natural approach: Language acquisition in the classroom. Pergamon.

Lee, Y. J., \& Cha, K. W. (2017). Listening logs for extensive listening in a self-regulated environment. The Asia-Pacific Education Researcher, 26(5), 271-279. https://doi.org/10.1007/s40299-017-0347-0

Renandya, W. A., \& Farrell, T. S. C. (2011). "Teacher, the tape is too fast!" Extensive listening in ELT. ELT Journal, 65(1), 52-29. https://doi.org/10.1093/elt/ccq015

Renandya, W. A. (2011). Extensive listening in the second language classroom in Widodo H.P., \& Ciroki, A. [Eds.], Innovation and creativity in ELT Methodology (pp.28-41). Nova Science Publisher.

Renandya, W. A., \& Jacobs, G. (2016). Extensive reading and listening in the L2 classroom. In W. A. Renandya \& P. Handoyo (Eds.), English Language Teaching Today (pp. 97-110). Springers.

Renandya, W. A., \& Hu, G. (2018). L2 listening in China: an examination of current practice. A. Burns and J. Siegel (eds.), International perspectives on teaching the four skills in ELT: International Perspectives on English Language Teaching.

Rost, M. (2011). Listening. In R. Carter \& D. Nunan (Eds.), Teaching English to Speakers of Other Languages (pp. 7-13). Cambridge University Press.

Setyowati, Y., \& Kuswahono, D. (2018). The Effect of Extensive Listening with "TED ED Video" to Promote Students' Proficiency in Listening. In The 1st International Conference on Education Language and Literature (ICONELITE) (pp. 261-264).

Spear-Swerling, L. (2016). Listening Comprehension. Perspective on Language and Literacy, 42(3), 9-15.

Su, R. Y., Fatmawati, \& Selamat, H. E. (2019). Fostering students' self-esteem in speaking by extending speaking activities in social media. Pedagogy Journal of English Language Teaching 7 (1), 65-74. https://ejournal.metrouniv.ac.id/index.php/pedagogy/article/view/1544 
EduLite Journal of English Education, Literature, and Culture

Vol. 6, No. 2, August 2021, pp. 314-325

E-ISSN: 2528-4479, P-ISSN: 2477-5304

http://jurnal.unissula.ac.id/index.php/edulite DOI: http://dx.doi.org/10.30659/e.6.2.314-325

Takaesu, A. (2013). Teaching Practice TED Talks as an Extensive Listening Resource for EAP Students. Language Education in Asia, 4(2), 150-162. https://camtesol.org/Download/LEiA_Vol4_Iss2_2013/Language_Education_in_ Asia_Vol4_Iss2_2013_C.pdf\#page=49

Tashakkori, A., \& Creswell, J. W. (2007). Editorial: the new era of mixed methods. $J$ Mixed Methods Res 1, 3-7.

Vandergrift, L., \& Goh, C. C. M. (2012). Teaching and learning second language listening: metacognition in action. Routledge

Waring, R. (2008). Starting extensive listening. Extensive reading in Japan, 1 (1), 7-9.

Widodo, H. P., \& Rozak, R. R. (2016). Engaging student teachers in collaborative and reflective online video-assisted extensive listening in an Indonesian initial teacher education (ITE) context. Electronic Journal of Foreign Language Teaching, 13 (2), 229-244.

Conflict of Interest Statement: The authors declare that the research was conducted in the absence of any commercial or financial relationships that could be construed as a potential conflict of interest.

Copyright (c) $2021 \mathrm{Su}$, Fatmawati, Guna, Jemadi, Mat, and De'e. This is an open-access article distributed under the terms of the Creative Commons Attribution License (CC BY). The use, distribution or reproduction in other forums is permitted, provided the original author(s) and the copyright owner(s) are credited and that the original publication in this journal is cited, in accordance with accepted academic practice. No use, distribution or reproduction is permitted which does not comply with these terms. 